\title{
PENGARUH IMPLEMENTASI STRATEGI DAN AUDIT INTERN TERHADAP KINERJA KEUANGAN
}

(Study pada Bank Umum di Tasikmalaya)

\author{
Wawan Sukmana \\ Tedi Rustendi \\ (Dosen Jurusan Akuntansi Fakultas Ekonomi Universitas Siliwangi Tasikmalaya) \\ Sani Santriyani \\ (Alumni Jurusan Akuntansi Fakultas Ekonomi Universitas Siliwangi Tasikmalaya)
}

\begin{abstract}
This research has purpose to get empirical proof ; 1) the influence of strategy implementation partially on financial performance, 2) the influence internal audit partially on financial performance, 3) the influence strategy implementation and internal audit simultaneously on financial performance. This research use descriptif analysis method with survey approach. The tool of analysis was used path analysis method to know the influence of strategy implementation and internal audit either partially or simultaneously on financial performance in public banks at Tasikmalaya city. The significant degree is 5\%. The result of the research are; 1) strategy implementation partially is not significant influence on financial performance in public banks at Tasikmalaya city, 2) Internal audit partially significant influence on financial performance in public Banks at Tasikmalaya city, and 3) Strategy implementation and internal audit simultaneously influence on financial performance in public Banks at Tasikmalaya city.
\end{abstract}

Key Word : Implementation of Strategy, Internal Audit, Financial Performance.

\section{Latar Belakang Penelitian}

Bank merupakan badan usaha komersial dengan tujuan mencari keuntungan bagi pemiliknya. Salah satu dari fungsi bank adalah menyediakan fasilitas rekening giro bagi nasabahnya. Bank-bank modem merupakan hasil dari perkembangan secara bertahap, yang dimulai dari para tukang emas yang menyediakan jasa penitipan uang dan barang barang berharga. Pada akhirnya menahan uang simpanan nasabah dengan cadangan kas, dan selebihnya ditanamkan pada surat berharga dan dipinjamkan dengan maksud memperoleh penghasilan.

Pelaksanaan kegiatan perbankan tersebut di atas, diperlukan strategi dengan harapan Bank dapat beroperasi sesuai dengan keinginan pemilik. Kemampuan Bank beroperasi berarti bank tersebut mempunyai kemampuan dalam memenangkan persaingan, mengingat keberadaan Bank cukup banyak, yang semuanya menawarkan kelebihan dan keuntungan pada nasabahnya. Dengan demikian peranan strategi dan implementasinya sangat diperlukan dalam kegiatan suatu Bank.Implementasi strategi adalah proses berbagai strategi dan kebijakan berubah menjadi tindakan melalui 
pengembangan program, anggaran dan preosedur. Walaupun implementasi biasanya baru dipertimbangkan setelah strategi disusun, sehingga implementasi strategi merupakan kunci sukses manajemen strategis. (Hunger, Wheelen, 2003)

Untuk memulai proses implementasi, manajer strategis harus memperhatikan beberapa aspek yaitu siapa yang akan melaksanakan rencana strategis yang telah disusun, apa yang harus dilakukan, bagaimana sumber daya manusia yang bertanggung jawab dalam implementasi akan melaksanakan berbagai hal yang diperlukan.

Pihak manajemen harus lebih dulu memusatkan perhatian pada pertanyaanpertanyaan tersebut ketika menganalisis pihak-pihak yang pro dan kontra terhadap alternatif strategi yang ditawarkan. Dalam setiap kesempatan, manajemen harus mempertimbangkannya sebelum merencanakan implementasi. Jika pihak manajemen tidak mampu menjawab pertanyaan-pertanyaan tersebut dengan memuaskan, maka sulit bagi strategi yang telah disusun dengan sempurna untuk dapat mencapai hasil yang diinginkan.

Untuk dapat mendukung implementasi strategi yang telah disusun, maka perlu pengawasan dari pimpinan perusahaan, dalam bentuk evaluasi dan perbaikan. Pelaksanaan teknis pengawasan tersebut dapat pula dilaksanakan oleh bagian audit intern. Dengan adanya evaluasi atas implementasi strategi, maka dapat diketahui kelemehan dan kekurangannya, sehingga dilakukan perbaikan baik dalam perencanaan maupun dalam pelaksanaannya. Hal tersebut dilakukan secara terus menerus (contineous improvement), sehingga diharapkan dapat mempengaruhi kinerja bank tsb.

\section{Rumusan Masalah}

Berdasarkan atas latar belakang yang telah diuraikan, maka identifikasi masalah dalam penelitian ini adalah sebagai berikut :

1. Bagaimana pengaruh implementasi strategi terhadap kinerja keuangan

2. Bagaimana pengaruh audit intern terhadap kinerja keuangan

3. Bagaimana pengaruh implementasi strategi dan audit intern secara simultan terhadap kinerja keuangan

\section{Kerangka Pemikiran}

Strategi perusahaan merupakan rumusan perencanaan komprehensif tentang bagaimana perusahaan akan mencapai misi dan tujuan. Strategi akan memaksimalkan keunggulan dan meminimalkan keterbatasan dengan demikian strategi merupakan kumpulan tindakan yang diarahkan untuk menjamin keunggulan bersaing yang terus menerus dipertahankan. Strategi merupakan alat untuk melakukan adaptasi dan merupakan faktor penentu (key determinant) kinerja perusahaan

Dalam model manajemen strategis menurut Hunger (2004), implementasi strategi merupakan langkah berikutnya setelah perumusan strategi. Dalam implementasi terdiri atas unsur program, anggaran dan prosedur, melalui ketiga tahap inilah implementasi strategi dapat dikatakan berjalan dengan baik. Apabila strategi dapat di implementasikan dengan baik sesuai dengan perumusan sebelumnya, maka akan berpengaruh pada kinerja perusahaan secara keseluruhan. Dalam Penelitian 
Wawan (2008) ditemukan bahwa strategi perusahaan berpengaruh pada kinerja keuangan pada kelompok perusahaan barang konsumsi yang listing di BEJ (sekarang BEI).

Implementasi adalah proses pelaksanaan dari suatu sistem yang baru, termasuk pelaksanaan sistem lama dan sistem baru secara bersamaan. Strategi merupakan alat untuk melakukan adaptasi dan merupakan faktor penentu (key determinant) kinerja perusahaan, sedangkan kinerja merupakan jantung keunggulan bersama (competitive advantage) dalam persaingan yang kompetitip. Bagaimana perusahaan mengimplementasikan strategi (strategy implementation) untuk beradaptasi dengan lingkungan merupakan makna dari orientasi strategis (strategic oriented) (Hunger, Wheelen, 2003)

Implementasi strategi merupakan salah satu tahap dari proses manajemen strategik yang diawali tahap perumusan strategi (strategy formulation) yang merupakan pengembangan rencana jangka panjang untuk menciptakan manajemen efektif melalui pengkajian atau kesmepatan dan ancaman linkungan, dilihat dari kekuatan dan kelemahan perusahaan.

Lebih lanjut Hunger Whelen (2003) mengemukakan pengertian implementasi strategi, bahwa implementasi strategi merupakan sejumlah totalitas aktivitas dan pilihan yang dibutuhkan untuk dapat menjalankan sebuah perencanaan strategis. Implementasi strategis merupakan proses berbagai strategi dan kebijakan berubah menjadi tindakan melalui pengembangan program, anggaran, dan prosedur.

Dari pengertian tersebut dapat disimpulkan bahwa implementasi strategi merupakan proses pelaksanaan strategi melalui pengembangan program, anggaran, dan prosedur. Implementasi strategi merupakan realisasi daripada strategi yang telah dipilih. Strategi yang telah dipilih harus dapat dilaksanakan secara konsisten dan untuk itu perlu dibangun suatu struktur organisasi yang cocok, anggaran yang memadai, sistem yang jelas dan kemampuan para pengelolanya.

Pandangan mengenai aspek implementasi strategi dikemukakan oleh Hitt etal (2005), bahwa implementasi strategi meliputi empat aspek yaitu :

1. Corporate governance, penerapan corporate governance dalam implementasi strategi diyakini oleh berbagai pihak dapat mengurangi tingkat kegagalan dalam pemantauan dan pengendalian keputusan strategi level manajemen puncak.

2. Struktur organisasi dan pengendalian, dalam implementasi strategi yang menjadi kendala adalah dalam level manajemen menengah dan manajemen operasional, oleh karenanya perlu ditumbuhkannya kreatifitas dan inovasi untuk membangun dan memberdayakan kompetensi inti perusahaan.

3. Kepemimpinan, faktor kepemimpinan memegang peran kunci, seorang pemimpin yang harus memiliki kualitas yang baik serta mampu memupuk semangat kebersamaan, kreativitas, inovasi dan melakukan pemberdayaan melalui perubahanperubahan ke arah perbaikan bersama.

4. Kewirausahaan dan inovasi, sikap kewirausahaan dan inovasi merupakan suatu yang tidak dapat diragukan lagi dalam rangka mennumbuh kembangkan suatu perusahaan. Perusahaan-perusahaan yang kuat dari aspek kewirausahaan dan 
inovasinya pada berbagai negara di dunia memberikan kontribusi yang besar terhadap perekonomian nasional. Dengan demikian unsur kewirausahaan dan inovasi harus hidup pada setiap perusahaan yang ingin berhasil dalam mengimplementasikan strateginya di tengah aktivitas bisnis.

Berdasarkan model manajemen strategi menurut Whelen Hunger( 2003) yang termasuk unsur implementasi strategi sebagai berikut:

1. Program

Di dalam implementasi strategi, langkah pertama yang harus dilakukan adalah penyusunan program atau pemograman (programming). Penyusunan program menghasilkan suatu rencana jangka panjang yang berisi langkah-langkah strategik yang dipilih untuk mewujudkan sasaran strategik tertentu beserta taksiran sumber daya yang diperlukan dalam aktivitas yang akan dilaksanakan. Melalui program akan diperoleh kerangka pedoman dalam penyusunan anggaran tahunan, mendorong seluruh lapisan manajer untuk berpikir lebih mendalam dan lebih sistematik mengenai masa depan perubahaan, dan menghilangkan kecenderungan yang wajar untuk memusatkan pada masalah darurat jangka pendek. Pembuatan program tidaklah berdiri sendiri tetapi proses terintegrasi dalam proses manajemen strategik yang menghubungkan antara tahap perumusan strategi dan tahap implementasi strategi.

Program dibuat bertujuan untuk membuat strategi dapat dilaksanakan dalam tindakan (action oriented). Dengan demikian program adalah merupakan pernyataan aktivitas atau langkah-langkah yang diperlukan untuk menyelesaikan perencanaan sekali pakai.

2. Anggaran

Setelah rencana aktivitas perusahaan ditetapkan dalam suatu program, maka setiap program yang akan dipilih akan dijadikan sebagai titik tolak dari penyusunan anggaran. Anggaran adalah program yang dinyatakan dalam bentuk satuan uang, setiap program akan dinyatakan secara rinci dalam biaya yang dapat digunakan oleh manajemen untuk merencanakan dan mengendalikan (Hunger Wheelen, 2003). Anggaran merupakan rencana manajemen mengenai kegiatan-kegiatan yang akan dilaksanakan dalam jangka waktu tertentu yang mencerminkan secara formal dan sistematis, kebijakan rencana-renaca, sasaran-sasaran tujuan yang hendak dicapai. Anggaran akan berhasil jika adanya bantuan dari tiap anggota manajemen dari semua jenjang, di sampaing itu penentuan atas pelaksanaan anggaran, dalam hal ini anggaran sangat diperlukan agar penyimpangan yang dihadapinya dapat ditekan.

3. Prosedur

Setelah program dan anggaran ditetapkan maka langkah berikutnya adalah penetapan prosedur. Prosedur merupakan alat yang dibuat untuk menyelesaikan sesuatu sesuai dengan kebijakan yang ditentukan oleh karena itu hal yang esensi adalah adanya keselarasan antara kebijakan yang ditetapkan dengan prosedur yang ditetapkan.

Prosedur adalah sistem langkah-langkah atau teknik-teknik yang berurutan menggambarkan secara rinci bagaimana suatu tugas atau pekerjaan diselesaikan. 
Prosedur secara khusus merinci berbagai aktivitas yang harus dikerjakan untuk menyelesaikan program-program perusahaan (Hunger Wheelen, 2003).

Audit intern merupakan kegiatan assurance dan konsultasi yang independen dan objektif yang dirancang untuk memberikan nilai tambah dan meningkatkan kegiatan operasi organisasi. Audit intern membantu organisasi untuk mencapai tujuannya, melalui suatu pendekatan yang sitematis dan teratur untuk mengevaluasi dan meningkatkan efektivitas pengelolaan risiko, pengendalian, dan proses governance. (Spencer Pickett, 2007).

Fungsi penilaian independent yang dibentuk dalam suatu organisasi dengan mengkaji dan mengevaluasi aktivitas organisasi sebagai bentuk jasa yang diberikan bagi organisasi. Untuk membantu para anggota organisasi agar dapat menjalankan tanggung jawabnya secara efektif. Memberi hasil analisis, penilaian, rekomendasi, konsleing dan informasi yang berkaitan dengan aktivitas yang dikaji dan menciptakan pengendalian efektif dengan biaya wajar. Sedangkan tujuan audit intern adalah memberi pelayanan kepada organisasi untuk membantu semua anggota organisasi tersebut. Bantuan yang diberikan sebagai tujuan akhir adalah agar semua anggota organisasi dapat melakukan tanggung jawab yang dibebankan kepadanya secara efektif.

Audit intern membantu manajemen dalam mencari kemungkinan yang paling baik dalam hal penggunaan sumber modal secara efektif dan efisien. Termasuk efektivitas pengendalian dalam barang-barang dengan biaya yang wajar. Semua bantuan audit intern tersebut dapat diberikan melalui analisis-analisis, penilaian, saran-saran, bimbingan dan informasi tentang aktivitas yang diperiksa.

Menurut Amin Widjaja Tunggal (2008), tujuan yang ingin dicapai audit intern adalah sebagai berikut :

1. Kelengkapan dan kebenaran informasi kegiatan perusahaan.

2. Penyesuaian dan penerapan kebijakan perusahaan, rencana kerja, prosedur, hal-hal yang diwajibkan dan hal-hal yang mencakup hukum dan peraturan yang berlaku.

3. Menjaga asset perusahaan terhadap penggunaan yang salah atau sewenang-wenang oleh pihak yang tidak berkepentingan.

4. Efektivitas, efisien dan kelengkapan organ operasi perusahaan untuk mencapai tujuan perusahaan.

Ruang lingkup kegiatan audit intern mencakup bidang yang sangat luas dan kompleks meliputi seluruh tingkatan manajemen baik yang sifatnya administrative maupun operasional. Ruang lingkup kegiatan audit intern menurut Spencer Pikcett (2007), adalah :

1. Pengendalian intern

a. Mengevaluasi kecukupan dan efektivitas sistem pengendalian intern, yang mencakup governance, kegiatan operasi dan sistem informasi perusahaan.

b. Meriview kegiatan operasi dan program untuk memastikan sampai sejauhmana hasil yang diperoleh konsistensi dengan tujuan dan sasaran yang telah ditetapkan.

2. Pengelolaan Risiko 
Mengidentifikasi dan mengevaluasi risiko signifikan dan memberikan kontribusi terhadap peningkatan pengelolaan risiko, dan sistem pengendalian intern.

3. Proses Governance

a. Menilai dan memberikan rekomendasi yang sesuai untuk meningkatkan proses governance dalam mencapai tujuannya.

b. Mengevaluasi rancangan, implementasi dan efektivitas dari kegiatan, program dan sasaran perusahaan yang berhubungan dengan etika untuk memastikan pengelolaan kinerja perusahaan yang efektif dan akuntabilitas.

Mengkoordniasi kegiatan antara pimpinan, dewan pengawas, auditor intern dan eksternal

Kinerja secara harfiah dapat diartikan sebagai prestasi atas kerja yang telah dilakukan. Seperti yang diungkapkan Wheelen dan Hunger (2004) bahwa kinerja merupakan hasil akhir dari aktivitas-aktivitas yang telah dilakukan, termasuk pula hasil dari proses manajemen stratejik. Jika hasil menunjukkan kesesuaian dengan rencana bahkan melebihi maka ini merupakan prestasi manajemen dalam menciptakan nilai. Nilai disini dapat diartikan sebagai kemakmuran bagi pemegang saham yang dapat direpresentasikan dengan harga saham dan dividen.

Kinerja yang baik menunjukkan bahwa perusahaan dapat meningkatkan kekayaan bagi pemegang sahamnya. Oleh karena itu pengukuran kinerja perusahaan diperlukan untuk menentukan keberhasilan perusahaan dalam memaksimalkan kekayaan pemegang perusahaan

Dalam literatur tentang pengukuran kinerja banyak menawarkan, contoh prosedur untuk mengidentifikasi, memilih dan mengimplementasikan ukuran kinerja yang tepat bagi perusahaan. Ukuran kinerja yang tepat memungkinkan perusahaan untuk mengarahkan tindakan mereka kearah pencapaian tujuan strategisnya (O'Mara et al , 1998). Tujuan utama pengukuran kinerja adalah membantu perusahaan untuk menentukan masalah pada kinerjanya dan berfokus pada efektifitas dan efisiensi perusahaan ( Yuksel, 2004). Oleh karena itu pengukuran kinerja dapat digunakan untuk menilai keberhasilan organisasi perusahaan (Kennerley and Neely, 2003).

Bagi perusahaan yang sebagian ekuitasnya dimiliki oleh masyarakat investor, mengakibatkan calon dan para investor sangat berkepentingan terhadap hasil yang seharusnya diperoleh dari penanaman dananya. Oleh karena itu kinerja keuangan perusahaan, tidak saja merupakan kepentingan pihak intern, melainkan juga kepentingan pihak eksternal

Untuk menilai kinerja perusahaan, biasanya investor akan melihat dan menganalisis laporan keuangan perusahaan yang bersangkutan. Selama ini laba akuntansi selalu menjadi fokus perhatian dalam menilai sebuah perusahaan. Namun dalam menilai kinerja perusahaan tidaklah cukup hanya menggunakan laba akuntansi saja, mengingat laba akuntansi hanya merupakan suatu outcome dari metode pencatatan yang didasarkan pada standar akuntansi keuangan.

Bagi perusahaan yang sebagian ekuitasnya dimiliki oleh masyarakat investor, mengakibatkan calon dan para investor sangat berkepentingan terhadap hasil yang 
seharusnya diperoleh dari penanaman dananya. Oleh karena itu kinerja keuangan perusahaan, tidak saja merupakan kepentingan pihak intern, melainkan juga
kepentingan pihak eksternal Dalam penelition keuangan dalam penelitian rasio yang digunakan penulis untuk mengukur kinerja karena bagi setiap perusahaan ROA digunakunakan indikator Return On Asset (ROA), seberapa besar perusahaan dapat menghasilk sebagai salah satu cara untuk mengukur menjadi salah satu ukuran bahwa perusahikan laba, karena laba yang besar tentu atau kinerjanya dipandang baik. merupakan rasio yang digunakan untuk dipilihnya Return On Asset ini karena perusahaan dalam menjalankan untuk mengukur tingkat efisiensi dan kemampuan menggunakan sumber-sumber pendapatan nal secara efektif dan efisien dalam pendapatan secara keseluruhan. Sematan untuk mengembangkan usaha menciptakan tinggi perusahaan menghasilkan. Semakin tinggi ROA yang dicapai maka semakin Berdasarkan penjasilkan profit (Agnes Sawir, 2008).

$\mathrm{H}_{\mathrm{H}}$ : Implementasi Strategi berpen dias, maka dlam penelitian ini diajukan hipotesis:

$\mathrm{H}_{2}$ : Audit Intern berpengaruh signifikah signifikan terhadap Kineja Keuangan.

\section{Metode Penelitian \\ Desain Penelitian}

Desain penelitian ini adalah survei, dengan menggunakan data primer dalam bentuk kuesioner. Responden dalam penelitian adalah auditor intern, dan pimpinan Bank yang

\section{Populasi dan Sampel Penelitian.}

Populasi adalah wilayah generalisasi yang terdiri dari atas objek/subjek yang mempunyai kualitas dan karakteristik tertentu yang ditetapkan oleh penelitian untuk dipelajari dan kemudian ditarik kesimpulannya (Sugiyono, 2007). Populasi dalam keeluruhan Bank Umum yang Bank Umum Cabang Tasikmalaya. Dimana secara Mengingat metode yang digunakan a oleh Kota Tasikmalaya ada 22 Bank Umum. sample. Untuk menentukan sampel penelitian aketode survey, maka perlu penarikan nonprobabiliti sampling dengan jenis purpos akan digunakan teknik penarikan sample keterbatasan akses dimana beberapa burposive sampling dengan alasan karena adanya subjek penelitian a responden bank umum konvensional menolak untuk dijadikan Umum Konvensa responden. Maka dari itu, penulis memilih 10 sampel Bank

Variabel Penelitian dan Operasional Variabel

Variabel Eksogen

1. Implementasi Strategi $\left(X_{1}\right)$

Implementasi strategi adalah proses dimana manajemen mewujudkan strategi dan kebijakannya dalam tindakan melalui pengembangan program, anggaran, dan prosedur (Hunger, Wheelen, 2004) . Variabel implementasi strategi, dibagi dalam Dimensi, Jurnal Akuntansi Riset, Prodi Akuntansi UPI, Vol. 1, No. 2 
program, anggaran, dan prosedur, dengan sejumlah indikator untuk masing-masing dimensi, yang diukur dalam bentuk skala Likerts.

2. Audit Intern $\left(\mathbf{X}_{2}\right)$.

Audit intern adalah kegiatan assurance dan konsultasi yang independen dan objektif yang dirancang untuk memberikan nilai tambah dan meningkatkan kegiatan operasi organisasi. Audit intern membantu organisasi untuk mencapai tujuannya, melalui suatu pendekatan yang sitematis dan teratur untuk mengevaluasi dan meningkatkan efektivitas pengelolaan risiko, pengendalian, dan proses governance. Variabel dioperasionalisasikan kedalam dimensi: evaluasi pengendalian intern, evaluasi pengelolaan risiko, dan evaluasi proses governance. Data diambil dengan kuisioner dalam bentuk skala Likert.

\section{Variabel Endogen (Y)}

Dalam penelitian ini yang menjadi variabel endogen adalah Kinerja keuangan. Variabel ini diukur dengan menggunakan rasio ROA, untuk Bank yang dijadikan sampel di Kota Tasikmalaya.

\section{Metode Analisis Data}

Sebelum melakukan analisis data terlebih dahulu dilakukan pengujian validitas dan reliabilitas terhadap data tersebut. Selanjutnya dilakukan analisis dengan melakukan pengujian hipotesis. Analisis data menggunakan model analisis path yang dibantu dengan program aplikasi SPSS versi $\mathbf{1 2 . 0}$

\section{Hasil Penelitian Dan Pembahasan}

\section{Uji Validitas dan Reliabilitas}

Tidak seluruh indikator variabel dinyatakan valid, terdapat satu indikator yang dinyatakan tidak valid. Mengingat jumlah indikator yang diajukan cukup banyak, maka indikator yang tidak valid diputuskan untuk dibuang. Data yang valid diuji reliabilitasnya dengan hasil seluruh variabel dinyatakan reliabel.

\section{Hasil Pengujian Hipotesis}

Pengaruh Secara Simultan Implementasi Strategi dan Audit Intern terhadap Kinerja Keuangan.

Besarnya pengaruh Implementasi Strategi $\left(\mathrm{X}_{1}\right)$ dan Audit Intern $\left(\mathrm{X}_{2}\right)$ terhadap Kinerja Keuangan (Y), dihitung melalui uji Path Analysis. Pengujian hipotesis secara simultan menggunakan uji $\mathrm{F}$ yaitu untuk menguji apakah terdapat pengaruh secara signifikan Implementasi Strategi dan Audit Intern terhadap Kinerja Keuangan yang dihitung menggunakan bantuan program SPSS versi 12.0.

Berdasarkan hasil analisis menggunakan program SPSS versi 12.0 diperoleh besarnya pengaruh secara simultan 0,771 atau $77,1 \%$. hal ini menunjukkan bahwa kedua variabel eksogen yakni; Implementasi Strategi dan Audit Intern secara bersama-sama dapat menjelaskan kinerja keuangan sebesar $77,1 \%$, selebihnya sebesar $22,9 \%$ dijelaskan oleh variabel lain diluar yang diteliti. Variabel lain yang diduga 
mempengaruhi kinerja keuangan diantaranya adalah; keunggulan bersaing, sistem pengendalian manajemen (Anthony \& Govindarajan, 2003)

Dari perhitungan SPSS, diperoleh nilai $F_{\text {hitung }}$ sebesar 114337.2 dengan kriteria penolakan $\mathrm{H}_{0}$, jika $\mathrm{F}_{\text {hitung }}>\mathrm{F}_{\text {tabel, }}$ atau dengan melihat nilai $\mathrm{F}$ sig sebesar 0,000 dan nilai ini lebih kecil dari 5\%, maka ini menunjukkan bahwa berpengaruh signifikan. Hal ini menunjukkan bahwa Implementasi Strategi dan Audit Intern berpengaruh signifikan terhadap Kinerja Keuangan.

\section{Pengaruh Implementasi Strategi Terhadap Kinerja Keuangan}

Berdasarkan hasil perhitungan yang diperoleh, implementasi strategi terhadap kinerja keuangan, sebesar $4,6 \%$ yang terdiri atas pengaruh langsung sebesar $0,2 \%$ dan pengaruh tidak langsung melalui audit intern sebesar 4,6\%. Disamping itu dari hasil pengujian signifikansi-nya diperoleh hasil bahwa koefisien sig. sebesar 0,141 , hal ini bermakna bahwa pengaruh implementasi strategi terhadap kinerja keuangan tidak signifikan. Pengaruh implementasi strategi terhadap kinerja keuangan, sangat kecil, hal ini kemungkinan karena Bank-bank umum yang dijadikan subyek penelitian belum mampu menerapkan strategi yang telah dirumuskan sebelumnya, atau kemungkinan pula strategi tsb tidak cocok diterapkan karena berbagai faktor kemungkinan diantaranya Tasikmalaya yang mempunyai visi Islami, sehingga mempengaruhi terhadap sikap masyarakatnya pada program-program Bank konvensional, sedangkan Bank umum yang dijadikan subyek pada penelitian ini berjenis konvensional bukan syariah.

\section{Pengaruh Audit Intern Terhadap Kinerja Keuangan}

Hasil perhitungan yang diperoleh, bahwa pengaruh audit intern secara langsung terhadap kinerja keuangan sebesar $68,1 \%$ sedangkan pengaruh tidak langsung melalui implementasi strategi sebesar $4,4 \%$, sehingga total pengaruhnya sebesar $72,5 \%$, dengan koefisien sig. sebesar 0,000. Hal ini bermakna bahwa semakin efektifnya audit intern, maka semakin tinggi kinerja keuangan Bank di Tasikmalaya.

\section{Simpulan}

Berdasarkan hasil analisis dan pembahasan, maka dapat dibuat kesimpulan sebagai
berikut:

1). Implementasi Strategi Berpengaruh tidak Signifikan terhadap kinerja keuangan, hal ini kemungkinan karena strategi sektor perbankan konvensional di Tasikmalaya berbeda dengan visi kota Tasikmalaya yang mengarah ke Islami.

2). Audit Intern berpengaruh signifikan terhadap kinerja keuangan.

3). Implementasi Strategi dan Audit Intern secara simultan berpengaruh signifikan terhadap kinerja keuangan pada Bank-bank umum di Tasikmalaya

\section{Keterbatasan.}

Penelitian ini mempunyai beberapa kelemahan yang membatasi kesempurnaannya, diantaranya adalah sebagai berikut: 
a. Pengukuran kinerja keuangan hanya oleh satu indikator, padahal memungkinkan beberapa indikator lain, misalnya ROE, Profit margin, EPS, dan lain-lain.

b. Data penelitian untuk variabel eksogen, diperoleh dari instrumen berdasarkan persepsi jawaban responden melalui kuesioner, sehingga kemungkinan ada responden yang tidak jujur dalam mengisi kuisioner.).

\section{Saran}

Berdasarkan simpulan yang telah dikemukakan di atas, penulis mencoba memberikan saran-saran yang diharapkan dapat memberikan manfaat yaitu sebagai berikut:

1). Bagi Bank-bank umum di Tasikmalaya

Dikarenakan implementasi strategi tidak berpengaruh signifikan terhadap kinerja keuangan pada Bank-bank umum di Tasikmalaya, maka hendaknya perlu direvisi kembali strategi yang disusunnya, menyesuaikan dengan visi Tasikmalaya.

2). Bagi peneliti selanjutnya

a) Bagi peneliti selanjutnya yang akan melakukan penelitian yang relevan, disarankan untuk ukuran variabel kinerja keuangan tidak hanya dengan satu Indikator ROA saja, akan tetapi menggunakan beberapa rasio keuangan lainnya dengan menggunakan metode Principal Component Analysis (PCA).

b) Model penelitian ini perlu ditindaklanjuti dengan diteliti kembali apakah dengan penambahan atau interaksi dengan variabel lain akan mengubah hasil terhadap kinerja keuangan Bank di Tasikmalaya..

c) Hendaknya peneliti selanjutnya tidak hanya mengumpulkan data yang berasal dari kuesioner, namun juga wawancara untuk mencocokkan jawaban responden secara nyata dan kuesioner, sehingga peneliti dapat melakukan kontrol atas jawaban responden (menghindari responden yang tidak jujur dalam mengisi kuesioner)

Daftar Pustaka

Agnes Sawir, 2008 , Analisis Lapora Keuangan, Salemba Empat Jakarta.

Amin Widjaya Tunggal, 2008, Audit Operasional suatu pengantar, Harvindo, Jakarta.

Hiro Tugiman, 2002, Standar Profesional Audit Internal; Yogyakarta, Kanisius

Hunger, Wheelen, 2004, Strategic Monagement. And Business Policy, New Jersey, Prentice Hall.

Kennerley, Mike and Andy Neely, 2003 ; Measuring Performance in a Changing business environment, International Journal Operations and Production Management. Bradford, Vol. 23, Iss.2; Pg 213-230

Pickett. K.H. Spencer, 2003 ; The Internal Auditor at Work ; Canada; John Willey \& Son Inc.

Porter, Michael, E, 2004, Competitive advantage, New York, Free Press.

Sekaran, Uma 2003, Research Methods For Business (A Skill Buildings Approach) Third edition, USA; John Willey \& Son. Inc,

Wawan Sukmana, 2008, Pengaruh Strategi Perusahaan dan Sistem Pengendalian Manajemen Terhadap Keunggulan Bersaing Serta Dampaknya Terhadap Kinerja Keuangan, Disertasi Universitas Padjadjaran, Bandung. 